DOI 10.4467/2543733XSSB.20.001.12199

PRZEMYSŁAW FAŁOWSKI

Instytut Filologii Słowiańskiej

Uniwersytet Jagielloński

\title{
STATUS TURCYZMÓW \\ WE WSPÓŁCZESNYM JĘZYKU CHORWACKIM - PRÓBA KLASYFIKACJI
}

\author{
Status of Turkish loanwords in the modern Croatian language \\ (attempts of classification)
}

Summary

In the 1990s, after the declaration of independence by Croatia, many Croatian linguists started to pursue a radical puristic language policy aimed at the elimination of foreign elements from the Croatian language, many Turkish loanwords as well.

The main purpose of the present publication is to investigate status, frequency and function of seven Turkish loanwords: ćošak, dućan, dugme, dušmanin, đubre, marama, maramica in modern Croatian. These words do have neutral synonyms that are native words and therefore, since the 1990s, were exposed to purist activities pursued by the Croatian linguists in dictionaries and popular language guides. This paper attempts to compare the thesis regarding this loanwords put forward by Croatian linguists with the usage in practise presented in online corpora. On this basis, regarding the intensity of language policy against Turkish loanwords as well as their frequency in journalistic and official texts, the preliminary classification of stylistically marked Turcisms was created.

Keywords: standard Croatian language, Turkish loanwords, linguistic purism, online corpora

Słowa kluczowe: chorwacki język standardowy, turcyzmy, puryzm językowy, korpusy językowe

Wyrazy pochodzenia tureckiego nie są obecnie przedmiotem szczególnego zainteresowania kroatystów w Chorwacji i poza nią, chociaż jeszcze w czasach byłej Jugosławii powstawały liczne prace na temat wpływów tureckich na ówczesny język serbsko-chorwacki, by wymienić najważniejszą z nich, czyli fundamentalną monografię autorstwa 
Abdulaha Škaljicia ${ }^{1}$. Z drugiej jednak strony, po rozpadzie Jugosławii jednym z najczęstszych tematów kroatystycznych opracowań naukowych i popularnonaukowych są wpływy serbskie na chorwacką normę językową, gdzie niejednokrotnie w poczet tzw. „serbizmów” włączone zostają również niektóre formy pochodzenia tureckiego. Jednym z nielicznych lingwistów, który po 1990 roku poświęcił swoją uwagę wyrazom o wyłącznie tureckiej proweniencji, był Dalibor Brozović ${ }^{2}$. Pomimo istnienia w chorwackim językoznawstwie innych terminów, badacz ten posłużył się w stosunku do analizowanych form określeniem turcizam, podkreślając, że chodzi o wyrazy, które weszły do języka chorwackiego za pośrednictwem tureckim. Są to najczęściej leksemy pochodzące z języków orientalnych, m.in. perskiego czy arabskiego, ale również np. z greki, stąd D. Brozović odrzuca proponowany przez Iva Pranjkovicia termin orijentalizam ${ }^{3}$. Chorwacki lingwista proponuje także dość ogólny podział turcyzmów na trzy grupy: 1) wyrazy neutralne stylistycznie, niemające rodzimego odpowiednika, np.: bakar, čarapa, dućan, duhan, kutija ..., 2) wyrazy opisujące orientalne/islamskie realia, np.: Bajram, baklava, džamija, fes, imam ..., 3) wyrazy nieużywane regularnie, posiadające swoje neutralne stylistycznie, rodzime ekwiwalenty (podane w nawiasie): barjak (zastava), sevdah (ljubav) ${ }^{4}$.

Wśród wymienionych powyżej typów zapożyczeń szczególnie ciekawe wydają się turcyzmy należące do trzeciej grupy, przede wszystkim ze względu na ich niepewny status we współczesnym języku chorwackim. Chociaż D. Brozović wymienia w obrębie tego zbioru tylko dwa leksemy, już wstępna ekscerpcja materiału ze słowników oraz poradników językowych pozwala poszerzyć tę grupę do kilkunastu, czy nawet kilkudziesięciu wyrazów. Warto podkreślić, że turcyzmy te, szczególnie w latach 90. - po ogłoszeniu przez Chorwację niepodległości - stały się przedmiotem intensywnej polityki językowej, mającej na celu usunięcie elementów serbskich z języka chorwackiego. Zostały więc, w opinii Henryka Jaroszewicza, mylnie napiętnowane jako serbizmy, a co za tym idzie - skazane na wymarcie ${ }^{5}$. Według Macieja Czerwińskiego chodzi o purystyczną politykę językową w skali mikro (tzw. ,planowanie języka”), skierowaną przeciwko elementom „niechorwackim” i prowadzoną w sposób niejednorodny i nieskoordynowany przez językoznawców chorwackich różnej proweniencji, szczególnie poprzez wydawanie licznych poradników językowych, słowników i artykułów ${ }^{6}$. Krakowski kroatysta podkreśla długą tradycję chorwackiego puryzmu (archaizującego, elitarystycznego, reformatorskiego, ksenofobicznego), który dzisiaj manifestuje się przede wszystkim niechęcią do bliżej niesprecyzowanych „serbizmów”, zaś antyserbizm stanowi ważny element składowy chorwackiego etosu narodowego ${ }^{7}$. Według Roberta D. Greenberga odrzucanie przez Chorwatów (i chorwackich językoznawców) elementów prawosławnych i orientalnych/islamskich ma jeszcze jedno źródło: chodzi mianowicie o podkreślenie miejsca języka chorwackiego w kontekście

\footnotetext{
${ }^{1}$ A. Škaljić, Turcizmi u srpsko-hrvatskom jeziku, „Svjetlost” Izdavačko preduzeće, Sarajevo 1966.

${ }^{2}$ D. Brozović, Odoše Turci, ostaše turcizmi, ,Vijenac”, 173, 2000.

${ }^{3}$ Za: S.Vranić, S. Zubčić, Turcizmi u frazemima hrvatskih govora, „Filologija”, 60, s. 111.

${ }^{4}$ D. Brozović, Odoše Turci, ostaše turcizmi.

${ }^{5}$ H. Jaroszewicz, Nowe tendencje normatywne w standardowych językach chorwackim i serbskim, Wydawnictwo Uniwersytetu Opolskiego, Opole 2004, s. 208.

${ }^{6}$ M. Czerwiński, Język - ideologia - naród. Polityka językowa w Chorwacji a język mediów, Scriptum, Kraków 2005, s. 91, 256.

${ }^{7}$ Ibidem, s. 50 .
} 
środkowoeuropejskim - w nadziei na wzmocnienie tożsamości europejskiej chorwackiego narodu i jeszcze większe odróżnienie go od narodu/języka serbskiego czy bośniackiego ${ }^{8}$. Takie purystyczne podejście do języka i tworzenie jego sztucznej (,czystej”) wersji było silnie krytykowane przez nielicznych chorwackich językoznawców liberalnej orientacji, m.in. Vladimira Anicia, który podkreślał wyjątkowość Chorwatów jako jedynego słowiańskiego narodu mającego w przeszłości bezpośredni kontakt z kulturą niemiecko-germańską, włosko-romańską i właśnie orientalną 9 .

Jak już wspomniano, wymienione powyżej aspekty chorwackiej polityki językowej wpłynęły na dzisiejszy status normatywny wyrazów tureckiego pochodzenia, szczególnie tych należących do trzeciej grupy w klasyfikacji D. Brozovicia. Ponieważ były to jednak działania nieskoordynowane, można zaryzykować hipotezę, że w zależności od rodzaju źródła oraz konkretnego turcyzmu stopień planowania języka jest inny. Poszczególne zapożyczenia $z$ języka tureckiego mają także odmienną frekwencję i konteksty użycia w różnych typach tekstów, co zapewne - obok skuteczności prowadzonej wobec nich polityki językowej - uzależnione jest m.in. od ich pojemności znaczeniowej oraz możliwości zastąpienia „lepszym” (najczęściej rodzimym) odpowiednikiem. Niniejszy artykuł stanowi próbę uporządkowania całego zagadnienia, a zarazem stworzenia wstępnej typologii owych problematycznych turcyzmów na podstawie relacji pomiędzy stopniem planowania ${ }^{10} \mathrm{a}$ ich rzeczywistą frekwencją w autentycznych chorwackich tekstach. Pod tym kątem poddane analizie zostaną wyrazy: ćošak 'róg, kąt' '11, dućan 'sklep'12, dugme 'guzik', dušman(in) 'wróg', đubre 'śmieci, gnój', marama, maramica 'chusta, chusteczka’ oraz ich najczęstsze, rodzime odpowiedniki ${ }^{13}$. Na początku poruszona zostanie kwestia ich pochodzenia oraz najstarszych poświadczeń na podstawie słownika JAZU ${ }^{14}$, następnie obecności i statusu normatywnego badanych turcyzmów w chorwackich słownikach, o różnym stopniu normatywności, z XX i XXI wieku ${ }^{15}$. W celu zba-

${ }^{8}$ R. Greenberg, Jezik i identitet na Balkanu. Raspad srpsko-hrvatskoga, tłum. Anita Peti-Stantić, Srednja Europa, Zagreb 2005, s. 132.

${ }^{9}$ Za: M. Czerwiński, Język - ideologia - naród. Polityka językowa w Chorwacji a język mediów, s. 76.

${ }^{10}$ Chodzi o tzw. ,planowanie korpusu języka” w ujęciu Heinza Klossa. Zob. H. Jaroszewicz, Nowe tendencje normatywne $w$ standardowych językach chorwackim i serbskim, s. 14-15, M. Czerwiński, Język-ideologia - naród. Polityka językowa w Chorwacji a język mediów, s. 39.

${ }^{11}$ Podawane są tutaj najpowszechniejsze, podstawowe znaczenia.

${ }^{12}$ Wyraz dućan należy, co prawda, do pierwszej grupy D. Brozovicia, jednakże już pobieżna analiza opracowań normatywnych sugeruje, że nie jest to forma neutralna, ponadto w tekstach jest ona stosowana w tych samych znaczeniach co ekwiwalenty trgovina i prodavaonica.

${ }^{13}$ Część z nich została już szczegółowo omówiona, choć pod trochę innym kątem, zob. P. Fałowski, Postavení, frekvence a funkce některých turcismů v současné chorvatštině, [w:] Studia Balkanica Bohemoslovaca; 7, Př́spěvky prednesené na VII. mezinárodním balkanistickém sympoziu v Brně ve dnech 28.-29. listopadu 2016, red. P. Boček, L. Hladký, P. Pilch, P. Stehlík, V. Štěpánek, Moravské zemské muzeum: Ústav slavistiky Filozofické fakulty Masarykovy univerzity, Brno 2017, s. 657-674. W niniejszym artykule przedmiotem analizy będą jedynie wymienione formy podstawowe, bez uwzględniania derywatów.

${ }^{14}$ Rječnik hrvatskoga ili srpskoga jezika, t. 1-23, Jugoslavenska Akademija Znanosti i Umjetnosti, Zagreb, 1880-1976.

${ }^{15}$ Chodzi o następujące pozycje jednojęzyczne: I. Broz, F. Iveković, Rječnik hrvatskoga jezika, Štamparija Karla Albrechta (Jos. Wittasek), Zagreb 1901 [skrót: BROZ]; J. Šonje (red.), Rječnik hrvatskoga jezika, LZ Miroslav Krleža i Školska knjiga, Zagreb 2000 [ŠONJE]; V. Anić, Veliki rječnik hrvatskoga jezika (elektronsko izdanje), Novi Liber, Zagreb 2003 [ANIĆ]; Lj. Jojić (red.), Veliki rječnik hrvatskoga standardnog jezika, Školska knjiga, Zagreb 2015 [VRH] oraz dwujęzyczne: J. Benešić, Stownik chorwacko-polski, Nakladni zavod hrvatske, 
dania natężenia planowania w stosunku do wybranych turcyzmów wykorzystanych zostanie osiem poradników językowych i słowników różnic z lat 90 . oraz początku $\mathrm{XX}$ wieku ${ }^{16}$. Na koniec te normatywne zalecenia zostaną zestawione $\mathrm{z}$ realnym uzusem językowym, reprezentowanym przez dwa chorwackie korpusy internetowe ${ }^{17}$, które posłużą do zbadania frekwencji turcyzmów w stosunku do ich ekwiwalentów w różnych typach tekstów (literackich, publicystycznych, urzędowych), a także, wraz z innymi źródłami internetowymi, jako źródło współczesnych znaczeń i kontekstów analizowanych wyrazów.

Zastanawiając się nad genezą omawianych turcyzmów, warto nawiązać do tezy turkologa Ekrema Čauševicia, który podkreśla, że chorwackich ziem, opanowanych w XVI wieku przez Imperium Osmańskie (Slawonia, Lika, Dalmacja), nie kolonizowali etniczni Turcy, lecz muzułmańscy osadnicy z terenów Bośni. Posługiwali się oni specyficznym idiomem języka tureckiego, opartym na gwarach zachodniej Rumelii i Bałkanów, określanym jako tzw. ,, bosanski” turski, który wpływał m.in. na adaptację fonologiczną wyrazów tureckich przed ich przeniknięciem do miejscowych gwar sztokawskich ${ }^{18}$. Spośród analizowanych leksemów większość zapożyczona została do języka tureckiego z języka perskiego, chodzi tu o wyrazy: ćošak < tur. köşe (köse) < pers. gasa (kūše)/ tur. küşk< pers. $k \bar{u} k^{19}$; dućan < tur. dükyari (dükkyan) < pers. dük'k'ân < arab. dükkân ${ }^{20}$; dugme < tur. dögme (düğme) < pers. tukme ${ }^{21}$ i dušmanin < tur. düşman < pers. dušmän $(\text { dušmen })^{22}$. Nieco odmienne, czyli arabskie pochodzenie mają turcyzmy marama (mahrama), maramica $\left(\right.$ mahramica) < tur. mahrama < arab. miqräm ${ }^{23}$, z kolei forma đubre wywodzi się $\mathrm{z}$ języka greckiego $\left(<\right.$ tur. göbre $=$ gübre $<$ grec. $\left.\kappa o ́ \pi \rho o \varsigma^{24}\right)$, nie jest więc właściwie orientalizmem.

Jak wynika z ekscerpcji materiału zawartego w słowniku historycznym JAZU, analizowane turcyzmy pojawiają się w chorwackim piśmiennictwie w różnych okresach. Najstarsze poświadczenia, bo już od XVI wieku, ma wyraz mahrama (w tej właśnie po-

\footnotetext{
Zagreb 1949 [BEN]; M. Deanović, J. Jernej, Hrvatsko ili srpsko-taljanski rječnik (wyd. 4.), Školska knjiga, Zagreb 1975 [DEAN]. Słowniki dwujęzyczne zostały włączone do analizy ze względu na brak reprezentatywnych źródeł normatywnych jednojęzycznych z okresu socjalistycznej Jugosławii.

${ }^{16}$ V. Brodnjak, Razlikovni rječnik srpskog i hrvatskog jezika, Školske novine, Zagreb 1991 [skrót: BROD]; M. Krmpotić, Jezični priručnik, Hrvatska radiotelevizija, Zagreb 1992 [KRM]; M. Šimundić, Rječnik suvišnih tuđica u hrvatskomu jeziku, Barka, Zagreb 1994 [ŠIM]; E. Barić (red.), Hrvatski jezični savjetnik, Institut za hrvatski jezik i jezikoslovlje, Zagreb 1999 [HJS]; I. Protuđer, Hrvatski u šaci, Naklada Protuđer, Split 2003 [PROT]; M. Matković, Jezični savjetnik, Škorpion, Zagreb 2006 [MAT]; L. Hudeček, M. Matković, I. Ćutuk, Jezični priručnik Coca-Cole HBC Hrvatska - hrvatski jezik o poslovnoj komunikaciji (wyd. 2.), Coca-Cola HBC Hrvatska d.o.o., Zagreb 2012 [HMĆ]; N. Opačić, Reci mi to kratko i jasno (wyd. 2.), Znanje, Zagreb 2015 [OPA].

${ }^{17}$ Hrvatski nacionalni korpus [HNK], http://filip.ffzg.hr/cgi-bin; Riznica Instituta za hrvatski jezik i jezikoslovlje [RIZNICA], http://riznica.ihjj.hr.

${ }^{18}$ Za: S. Vranić, S. Zubčić, Turcizmi u frazemima hrvatskih govora, s. 111.

${ }^{19}$ P. Skok, Etimologijski rječnik hrvatskoga ili srpskoga jezika, t. 1-4, Zagreb 1971-1974, t. I, s. 361; Hrvatski jezični portal, http://hjp.znanje.hr/.

${ }^{20}$ P. Skok, Etimologijski rječnik hrvatskoga ili srpskoga jezika, t. 1, s. 451; Hrvatski jezični portal.

${ }^{21}$ P. Skok, Etimologijski rječnik hrvatskoga ili srpskoga jezika, t. 1, s. 454; Hrvatski jezični portal.

${ }^{22}$ P. Skok, Etimologijski rječnik hrvatskoga ili srpskoga jezika, t. 1, s. 462; Hrvatski jezični portal.

${ }^{23}$ Hrvatski jezični portal.

${ }^{24}$ P. Skok, Etimologijski rječnik hrvatskoga ili srpskoga jezika, t. 1, s. 482.
} 
staci z pierowotnym fonemem $h$ ), występujący najczęściej w znaczeniu różnych elementów kobiecego stroju (lub jako rodzaj serwety) w dziełach dawnych twórców dalmatyńskich (Juraj Baraković) i dubrownickich (Junije Palmotić), a także u XVIII i XIX-wiecznych chorwackich leksykografów (Ivan Belostenec, Joakim Stulli) ${ }^{25}$. Forma deminutywna - mahramica - ma najstarsze poświadczenia z XVII wieku. U chorwackich pisarzy i leksykografów (m.in. Ivan Gundulić; Ardelio Della Bella, Ivan Belostenec) funkcjonuje jako część ubioru, z kolei w serbskim słowniku Vuka Karadžicia (wydanie z 1852 ro$\mathrm{ku}$ ) pojawia się ponadto w dwóch nowych, zoologicznych znaczeniach: 'śródjelicie' i 'podgardle'26. Z XVII wieku, jak podaje słownik JAZU, pochodzą także najdawniejsze zapisy turcyzmów dućan i dušmanin; pierwszy z nich, oprócz wymienionych źródeł leksykograficznych, obecny jest m.in. w XVIII-wiecznej twórczości autorów slawońskich Stjepana Margiticia i Antuna Kanižlicia (znaczenie 'miejsce, gdzie się coś sprzedaje')27, $\mathrm{z}$ kolei dušmanin ('wróg') występuje ponadto w słynnej księdze Razgovor ugodni naroda slovinskoga (1759) autorstwa Andriji Kačicia Miošicia z Dalmacjii ${ }^{28}$. Pozostałe turcyzmy pojawiają się w chorwackim piśmiennictwie dopiero w XVIII wieku, w tym lokalne warianty marama, maramica (bez fonemu $h$ ) używane przez licznych pisarzy z różnych obszarów ówczesnej Chorwacji w odniesieniu do części ubioru. Warto odnotować, że te pierwotne znaczenia zostają rozszerzone w pracy serbskiego biologa Josifa Pančicia Zoologija (1872), zyskując status terminów: marama 'błona śuzowa', maramica 'opłucna', co nie pozostanie bez wpływu na ich późniejsze funkcjonowanie w języku serbsko-chorwackim, a później również chorwackim ${ }^{29}$. Podobną sytuację można zaobserwować w przypadku turcyzmów ćošak i đubre, które u chorwackich pisarzy i leksykografów z XVIII wieku występują w pierwotnych znaczeniach (odpowiednio 'kąt, róg' i 'nawóz'), u serbskich autorów z XIX wieku (m.in. V. Karadžić, M. Đ. Miličević) otrzymują zaś znaczenia dodatkowe (ćošak 'altana' ${ }^{30}$, đubre 'duży i leniwy człowiek') ${ }^{31}$. Ostatni typ turcyzmów reprezentują formy dugme 'guzik' i dušman 'wróg', które pojawiają się w nielicznych XVIII-wiecznych zabytkach chorwackich, są natomiast powszechne w źródłach serbskich z XIX wieku².

Interesujących wyników dostarcza zestawienie obecności i statusu analizowanych turcyzmów w różnorakich słownikach chorwackich z XX i XXI wieku (por. Tabela 1) ${ }^{33}$.

${ }^{25}$ Rječnik hrvatskoga ili srpskoga jezika, t. 6, s. 382.

${ }^{26}$ Ibidem, t. 6, s. 383.

${ }^{27}$ Ibidem, t. 2, s. 852.

${ }^{28}$ Ibidem, t. 2, s. 905.

${ }^{29}$ Ibidem, t. 6, s. 468.

${ }^{30}$ Trzeba podkreślić, że formy te w poszczególnych znaczeniach mają nieco odmienne pochodzenie, w związku z czym występują pewne różnice akcentowe: ćǒsak (akcent krótki rosnący) 'kąt, róg', ćöšak (akcent krótki opadający) 'altana'.

${ }_{31}^{31}$ Ibidem, t. 2, s. 43; t. 3, s. 10-11.

${ }^{32}$ Ibidem, t. 2, s. $864,905$.

${ }^{33} \mathrm{~W}$ tabeli znakiem ,,+” oznaczono obecność danej formy w konkretnym źródle, w przypadku obecności dwóch wariantów danego wyrazu (np. marama, mahrama) pojawiają się dwa znaki „,+. Jeśli w danym słowniku występuje nowe znaczenie któregoś z turcyzmów, znajduje się ono w nawiasie kwadratowym. W niektórych źródłach pojawiają się ponadto warianty preferowane (neutralne stylistycznie), które sygnalizuje znak $\rightarrow$. Obecne w słownikach kwalifikatory stylistyczne (np. reg., razg.) pozostawiono w postaci oryginalnej. Turcyzmy zostały uporządkowane w kolejności od najbardziej neutralnych do najbardziej nacechowanych stylistycznie. 
Wyróżnia się tu z pewnością słowo dušmanin, które w tej właśnie postaci pojawia się we wszystkich analizowanych słownikach jako forma neutralna ${ }^{34}$. W przypadku turcyzmów ćošak, marama i maramica preferowanie rodzimych odpowiedników można zaobserwować już w dwujęzycznym słowniku z 1975 roku, gdzie przy wspomnianych formach występują słowiańskie ekwiwalenty, z kolei przy wariantach rodzimych brak odwołania do ich ,gorszych” odpowiedników ${ }^{35}$. Pozostałe wyrazy zmieniają swój status stylistyczny dopiero w słownikach z XXI wieku, przy czym każde źródło traktuje poszczególne turcyzmy nieco odmiennie, np. w słowniku Jura Šonja wyrazy dugme i dućan zostają uznane za neutralne ${ }^{36}$, z kolei w opracowaniu Vladimira Anicia taka kwalifikacja pojawia się przy hasłach dugme oraz częściowo đubre i maramica ${ }^{37}$. W słowniku V. Anicia i w najnowszym opracowaniu leksykograficznym (VRH) przy turcyzmach występują różnorakie kwalifikatory, np. u V. Anicia słowa dućan, ćošak i marama uznane zostają za regionalizmy (kwalifikator reg.) ${ }^{38}$, a w słowniku z 2015 roku jako potoczne (razg.) określone są leksemy dućan, ćošak i đubre ${ }^{39}$. U J. Šonja oraz w najnowszym słowniku przy większości analizowanych turcyzmów pojawiają się odnośniki do neutralnych stylistycznie form, przy których występuje dokładna definicja wyrazów: u Šonja dotyczy to leksemów: đubre, ćošak, marama i maramica ${ }^{40}$, a w słowniku z 2015 roku - ponadto dugme i dućan ${ }^{41}$. Warto również zwrócić uwagę na dodatkowe znaczenia wspominanych tu turcyzmów, np. w przypadku leksemu dugme, wraz ze zmianą realiów, w nowszych słownikach pojawia się znaczenie 'przycisk', przy słowie ćošak odwrotnie: dawne znacznie 'balkon, altana' zanika, choć wymienia je jeszcze V. Anić ${ }^{42}$. Ciekawsza sytuacja ma miejsce w przypadku turcyzmów đubre i maramica: pierwszy z nich w nowszych słownikach jest kojarzony m.in. $\mathrm{z}$ dawnym serbskim pejoratywnym określeniem człowieka ${ }^{43}, \mathrm{z}$ kolei drugi zachowuje dawne znaczenie anatomiczne (zoologiczne) ${ }^{44}$. Ponadto w słowniku V. Anicia przeniesione użycia wyrazów đubre i maramica uznane zostają za serbskie i oznaczone kwalifikatorem $\operatorname{srp}^{45}$

${ }^{34}$ Pewne wątpliwości może budzić jedynie wskazówka w słowniku z 1901 roku, aby dokładnej definicji wyrazu szukać pod hasłem neprijatelj. Por. I. Broz, F. Iveković, Rječnik hrvatskoga jezika, t. 1, s. 277.

${ }^{35}$ M. Deanović, J. Jernej, Hrvatsko ili srpsko-taljanski rječnik, s. 82, 289, 314, 319, 691, 695.

${ }^{36}$ J. Šonje, Rječnik hrvatskoga jezika, s. 218, 219.

${ }^{37} \mathrm{~V}$. Anić, Veliki rječnik hrvatskoga jezika.

${ }^{38}$ Ibidem.

${ }^{39}$ Lj. Jojić, Veliki rječnik hrvatskoga standardnog jezika, s. 159, 237, 250.

${ }^{40}$ J. Šonje, Rječnik hrvatskoga jezika, s. 153, 572.

${ }^{41}$ Lj. Jojić, Veliki rječnik hrvatskoga standardnog jezika, s. 159, 237, 238, 250, 707.

${ }^{42}$ V. Anić, Veliki rječnik hrvatskoga jezika.

${ }^{43}$ J. Šonje, Rječnik hrvatskoga jezika, s. 153; V. Anić, Veliki rječnik hrvatskoga jezika; Lj. Jojić, Veliki rječnik hrvatskoga standardnog jezika, s. 250.

${ }^{44}$ J. Šonje, Rječnik hrvatskoga jezika, s. 572; V. Anić, Veliki rječnik hrvatskoga jezika; Lj. Jojić, Veliki rječnik hrvatskoga standardnog jezika, s. 707.

${ }^{45} \mathrm{~V}$. Anić, Veliki rječnik hrvatskoga jezika. 
Tabela 1. Turcyzmy w słownikach chorwackich (1901-2015)

\begin{tabular}{|c|c|c|c|c|c|c|}
\hline Forma & $\begin{array}{c}\text { BROZ } \\
1901\end{array}$ & $\begin{array}{l}\text { BEN } \\
1949\end{array}$ & $\begin{array}{c}\text { DEAN } \\
1975\end{array}$ & $\begin{array}{c}\text { ŠONJE } \\
2000\end{array}$ & $\begin{array}{c}\text { ANIĆ } \\
2003\end{array}$ & $\begin{array}{l}\text { VRH } \\
2015\end{array}$ \\
\hline $\begin{array}{c}\text { dušmanin } \\
\text { dušman }\end{array}$ & $\begin{array}{c}++ \\
\text { vidi } \\
\text { neprijatelj } \\
\end{array}$ & ++ & ++ & $\begin{array}{c}+ \\
\text { dušmanin }\end{array}$ & ++ & $\stackrel{+}{+} \underset{\text { dušmanin }}{+}$ \\
\hline dugme & + & $\begin{array}{c}+ \\
\text { ['spinka'] }\end{array}$ & $\begin{array}{c}+ \\
\text { ['przycisk'] }\end{array}$ & + & $\begin{array}{c}+ \\
\text { ['przycisk'] }\end{array}$ & $\begin{array}{c}+ \\
\rightarrow \text { puce } \\
\rightarrow \text { tipka } \\
\text { ['przycisk'] }\end{array}$ \\
\hline dućan & + & + & + & + & $\begin{array}{c}+ \\
\text { reg. } \\
\text { ['handel', } \\
\text { 'rozporek'] }\end{array}$ & $\begin{array}{c}+ \\
\text { razg. } \rightarrow \\
\text { prodavaonica, } \\
\text { trgovina }\end{array}$ \\
\hline dubre & $\begin{array}{c}+ \\
{[\text { kola }} \\
\text { gjubreta } \\
\text { 'duży } \\
\text { i leniwy } \\
\text { człowiek'] }\end{array}$ & $\begin{array}{c}+ \\
\text { [‘śmieci’] }\end{array}$ & $\begin{array}{c}+ \\
\text { ['zła, bez- } \\
\text { wartościowa } \\
\text { osoba'] }\end{array}$ & $\begin{aligned} &+ \\
& \rightarrow \text { gnoj } \\
& \rightarrow \text { smeće } \\
& \rightarrow \text { ološ }\end{aligned}$ & $\begin{array}{c}+ \\
\text { ['coś bez- } \\
\text { wartościowego', } \\
\text { 'zła, } \\
\text { bezwartościowa } \\
\text { osoba', reg. srp. } \\
\text { 'śmieci'] }\end{array}$ & $\begin{array}{c}+ \\
\text { razg. vulg. } \\
\rightarrow \text { smeće } \\
\rightarrow \text { ološ } \\
\text { ['zła, } \\
\text { bezwartościowa } \\
\text { osoba'] }\end{array}$ \\
\hline ćošak & $\begin{array}{c}+ \\
\text { ['altana'] }\end{array}$ & $\stackrel{+}{+}$ & $\begin{array}{c}+ \\
(k u t)\end{array}$ & $\begin{array}{c}+ \\
\rightarrow \text { ugao } \\
\rightarrow \text { kut }\end{array}$ & $\begin{array}{c}+ \\
\text { reg. } \\
\text { ['balkon'] }\end{array}$ & $\begin{array}{c}+ \\
\text { reg. razg. } \\
\rightarrow \text { ugao } \\
\rightarrow \text { kut }\end{array}$ \\
\hline $\begin{array}{c}\text { marama } \\
\text { mahrama }\end{array}$ & ++ & ++ & $\begin{array}{c}++ \\
\text { marama } \\
\text { (rubac) } \\
\text { mahrama reg. }\end{array}$ & $\begin{array}{c}+ \\
\text { marama } \\
\rightarrow \text { rubac }\end{array}$ & $\begin{array}{c}+ \\
\text { marama } \\
\text { reg. }\end{array}$ & $\begin{array}{c}+ \\
\text { marama } \\
\rightarrow \text { rubac }\end{array}$ \\
\hline $\begin{array}{c}\text { maramica } \\
\text { mahramica }\end{array}$ & $\begin{array}{c}++ \\
\text { ['środjelicie', } \\
\text { 'podgardle'] }\end{array}$ & $\begin{array}{c}+ \\
\text { maramica } \\
\text { ['podgardle', } \\
\text { 'opłucna'] }\end{array}$ & $\begin{array}{c}+ \\
\text { maramica } \\
\text { (rupčić) } \\
\text { ['śródjelicie', } \\
\text { 'opłucna'] }\end{array}$ & $\begin{array}{c}+ \\
\text { maramica } \\
\rightarrow \text { rupčić } \\
\rightarrow \\
\text { ovojnica } \\
\text { ['osłona, } \\
\text { błona'] }\end{array}$ & $\begin{array}{c}+ \\
\text { maramica } \\
\text { [srp. 'osłona, } \\
\text { błona'] }\end{array}$ & $\mid \begin{array}{c}\quad+ \\
\text { maramica } \\
\rightarrow \text { džepni rubac, } \\
\text { rupčić }\end{array}$ \\
\hline
\end{tabular}

W największej mierze intensywna polityka językowa wobec turcyzmów (a zarazem serbizmów) obecna była w bardzo licznych poradnikach językowych i słownikach różnic powstałych po 1990 roku $^{46}$, jednakże publikacje te - jak i zawarte w nich tendencje purystyczne - mają w Chorwacji znacznie dłuższą tradycję. Warto przywołać tutaj przynajmniej trzy źródła. Pierwsze z nich to wydana w 1937 roku w Warszawie - stąd mniej znana wśród Chorwatów - gramatyka języka chorwackiego, której autor, Julije Benešić, jako jeden z pierwszych zamieszcza słowniczek różnic pomiędzy chorwackim a serbskim wariantem wspólnego jeszcze wtedy języka. Wśród ponad tysiąca haseł znalazło się miejsce dla dwóch

${ }^{46}$ Dokładne omówienie tego cyklu tekstów znajduje się w opracowaniu M. Czerwińskiego, Język-ideologia-naród. Polityka językowa w Chorwacji a język mediów, s. 91-130. 
analizowanych tutaj turcyzmów đubre i marama, które uznane zostały za warianty serbskie o chorwackich odpowiednikach gnojivo i rubac ${ }^{47}$. Wydany trzy lata później, w okresie autonomicznej Banowiny Chorwacji, znacznie bardziej popularny słownik różnic chorwacko-serbskich autorstwa Petara Guberiny i Kruna Krsticia stawiał sobie za cel wyeliminowanie $\mathrm{z}$ języka chorwackiego wpływów obcych ${ }^{48}$. Jego autorzy byli jednak dość pobłażliwi w stosunku do analizowanych tu turcyzmów, uznając jedynie formy ćošak i đubre za gwarowe, które należy zastąpić rodzimymi odpowiednikami ${ }^{49}$. Ostatnie ze źródeł to powstały w okresie socjalistycznej Jugosławii słownik ortograficzny autorstwa Stjepana Babicia, Božidara Finki i Milana Moguša (tzw. Londonac), swoisty manifest tzw. „chorwackiej wiosny" (Hrvatsko proljeće), który pomimo funkcji poradnika poprawnej pisowni, zawiera pewne purystyczne zalecenia dotyczące chorwackiej leksyki. W analizowanym tutaj czwartym wydaniu słownika występuje planowanie w stosunku do turcyzmów ćošak i đubre, które są traktowane jako formy zbyteczne lub gorsze ${ }^{50}$.

Począwszy od lat 90. XX wieku, wraz z ogłoszeniem przez Chorwację niepodległości, polityka językowa w skali mikro w stosunku do turcyzmów zyskuje na intensywności (por. Tabela 2$)^{51}$. Jak wynika $\mathrm{z}$ analizy ośmiu źródeł o charakterze poradnikowym z końca XX i początku XXI wieku, zakres planowania uzależniony jest od konkretnego źródła (np. w HJS zakres ten jest znacznie szerszy niż w MAT czy OPA), a co za tym idzie, w różnym stopniu dotyczy poszczególnych wyrazów. Autorzy poradników w najmniejszej mierze rugowali z języka chorwackiego turcyzmy dušman/dušmanin (2 na 8 źrodeł) oraz dućan (3/8), a w największej - leksemy marama i đubre (6/8). Nacechowanie stylistyczne turcyzmów, a zarazem ich stosunek do form neutralnych są różnie oceniane, np. ćošak w zależności od źródła uznawany jest za formę: gorszą (BROD), zbyteczną (ŠIM), regionalizm (HJS) czy niepotrzebną (obca) $(\mathrm{PROT})^{52}$, z kolei maramica może być formą gorszą (BROD), serbską (KRM) lub potoczną $(\mathrm{HJS})^{53}$. Na tle pozostałych opracowań zaskakiwać może poradnik z 2012 roku (HMĆ) regulujący komunikację językową w dużej korporacji - turcyzm dugme występuje w nim jako forma poprawna w stosunku do niezalecanego synonimu gumb $b^{54}$. Analiza porównawcza poradników pozwala na dość ostrożne stwierdzenie, że po roku 2000 natężenie planowania językowego w stosunku do turcyzmów spada. Może także o tym świadczyć fakt, że w najnowszym

\footnotetext{
${ }^{47}$ J. Benešić, Gramatyka języka chorwackiego, czyli serbskiego, Bibljoteka Polska, Warszawa 1937, s. 238, 251.

${ }^{48}$ Por. M. Czerwiński, Język - ideologia - naród. Polityka językowa w Chorwacji a język mediów, s. 97.

${ }^{49} \mathrm{Za}$ I. Pranjković, O aktualnosti Matičina razlikovnog rječnika iz 1940. godine, [w:] I. Pranjković, Ogledi o jezičnoj pravilnosti, Disput, Zagreb 2010, s. 152.

${ }^{50}$ S. Babić, B. Finka, M. Moguš, Hrvatski pravopis: s pravopisnim rječnikom, wyd. 4, Školska knjiga, Zagreb 1996, s. 189, 210.

${ }^{51} \mathrm{~W}$ tabeli wymienione zostały preferowane przez autorów poradników/słowników ekwiwalenty badanych turcyzmów. W przypadku większości źródeł (BROD, HJS, PROT, HMĆ, OPA) pojawiają się różne oznaczenia „gorszych” form w zależności od ich stosunku do wyrazów uznanych za neutralne. W tych sytuacjach zachowano pierwotne symbole graficzne $(>, \rightarrow,-)$, aby pokazać, że podejście autorów poradników do poszczególnych turcyzmów jest zróżnicowane, ale zarazem niespójne i nieskoordynowane. Kolejność leksemów w tabeli ma na celu odzwierciedlenie natężenia planowania w stosunku do nich, od najmniejszego do największego.

${ }^{52}$ V. Brodnjak, Razlikovni rječnik srpskog i hrvatskog jezika, s. 75; M. Šimundić, Rječnik suvišnih tuđica u hrvatskomu jeziku, s. 20; E. Barić, Hrvatski jezični savjetnik, s. 454; I. Protuđer, Hrvatski u šaci, s. 106.

${ }^{53}$ V. Brodnjak, Razlikovni rječnik srpskog i hrvatskog jezika, s. 275; M. Krmpotić, Jezični priručnik, s. 190; E. Barić, Hrvatski jezični savjetnik, s. 806.

${ }^{54}$ L. Hudeček, M. Matković, I. Ćutuk, Jezični priručnik Coca-Cole HBC Hrvatska-hrvatski jezik o poslovnoj komunikaciji, s. 173.
} 
opracowaniu autorstwa Nives Opačić warianty marama/rubac i maramica/rupčić funkcjonują jako równoprawne ${ }^{55}$. Z drugiej jednak strony do dzisiaj w popularnych środkach przekazu a dokładniej w pierwszym programie Chorwackiego Radia (HR 1)-usłyszeć można wypowiedzi językoznawców piętnujących użycie turcyzmów. Chodzi o jeden z odcinków audycji Govorimo hrvatski, dotyczący nazw guzika (Što zakapčamo?, 19.01.2015), którego autorka starała się wykazać wyższość rodzimej postaci puce nad zapożyczeniami dugme i gumb ${ }^{56}$.

Tabela 2. Turcyzmy w poradnikach językowych (1991-2015)

\begin{tabular}{|c|c|c|c|c|c|c|c|c|}
\hline Forma & $\begin{array}{c}\text { BROD } \\
1991\end{array}$ & $\begin{array}{c}\text { KRM } \\
1992\end{array}$ & $\begin{array}{l}\text { ŠIM } \\
1994\end{array}$ & $\begin{array}{l}\text { HJS } \\
1999\end{array}$ & $\begin{array}{c}\text { PROT } \\
2003\end{array}$ & $\begin{array}{l}\text { MAT } \\
2006\end{array}$ & $\begin{array}{l}\text { HMĆ } \\
2012\end{array}$ & $\begin{array}{l}\text { OPA } \\
2015\end{array}$ \\
\hline $\begin{array}{c}\text { dušmanin } \\
\text { dušman }\end{array}$ & & & $\begin{array}{c}\text { neprijatelj, } \\
\text { protivnik }\end{array}$ & $\begin{array}{c}\vec{\rightarrow} \\
\text { neprijatelj }\end{array}$ & & & & \\
\hline dućan & & & prodavaonica & $\begin{array}{c}\text { razg. } \\
- \\
\text { trgovina }\end{array}$ & & & $\begin{array}{l}>\text { proda- } \\
\text { vaonica } \\
\text { trgovina }\end{array}$ & \\
\hline ćošak & $\begin{array}{c}\text { > ugao } \\
\text { kut }\end{array}$ & & $\begin{array}{c}\text { ugao, kut; } \\
\text { izturena } \\
\text { soba; } \\
\text { balkon }\end{array}$ & $\begin{array}{c}\text { pokr. } \\
- \\
k u t, \text { ugao }\end{array}$ & $\begin{array}{c}- \\
\text { kut, } \\
\text { ugao }\end{array}$ & & & \\
\hline maramica & $\begin{array}{l}\text { > rupčić, } \\
\text { rupčić za nos }\end{array}$ & rupčić & & $\begin{array}{c}\text { razg. } \\
- \text { rupčić }\end{array}$ & & & \begin{tabular}{|} 
> rupčić; \\
papirnate \\
maramice \\
> papirnati \\
rupčići
\end{tabular} & $\begin{array}{c}\text { maramical } \\
\text { rupčić }\end{array}$ \\
\hline dugme & > puce, gumb & $\begin{array}{l}\text { puce, } \\
\text { putac }\end{array}$ & $\begin{array}{c}\text { putce, spona, } \\
\text { dirka }\end{array}$ & $\begin{array}{c}\text { > puce, } \\
\text { gumb }\end{array}$ & $\begin{array}{c}> \\
\text { puce }\end{array}$ & & $\begin{array}{c}\text { gumb } \\
>\text { dugme, } \\
\text { puce; } \\
\text { tipkalo }\end{array}$ & \\
\hline marama & $\begin{array}{c}\text { > rubac, } \\
\text { ubrus }\end{array}$ & $\begin{array}{l}\text { rubac } \\
\text { ubrus }\end{array}$ & $\begin{array}{c}\text { rubac, ubrus; } \\
\text { ručnik }\end{array}$ & $\begin{array}{c}\rightarrow \text { rubac } \\
\text { ubrus }\end{array}$ & $\begin{array}{c}\text { >rubac, } \\
\text { ubrus }\end{array}$ & rubac & & $\begin{array}{c}\text { maramal } \\
\text { rubac }\end{array}$ \\
\hline dubre & $\begin{array}{c}\text { (hd) - } \\
\text { smeće, } \\
\text { nečistoća, } \\
\text { nečist; } \\
\text { ustajali } \\
\text { i nagomilani } \\
\text { stočni izmet, } \\
\text { gnoj; gnoj iz } \\
\text { rane; nešto } \\
\text { sto je slabo, } \\
\text { male ili } \\
\text { nikakve } \\
\text { vrijednosti; } \\
\text { ljudski ološ, } \\
\text { smeće }\end{array}$ & $\begin{array}{c}\text { smeće, } \\
\text { nečistoća, } \\
\text { nečist, } \\
\text { ljudski } \\
\text { ološ }\end{array}$ & $\begin{array}{l}\text { gnoj, } \\
\text { gnojivo, } \\
\text { smeće }\end{array}$ & $\begin{array}{l}\rightarrow \text { gnoj; } \\
\text { smeće }\end{array}$ & $\begin{array}{l}\text { - smeće } \\
\text { stočni } \\
\text { izmet } \\
\text { (gnoj), } \\
\text { gnoj iz } \\
\text { rane }\end{array}$ & & & $\begin{array}{c}\rightarrow \text { gnoj, } \\
\text { razg. } \\
\text { đubre } \\
\text { jedno }\end{array}$ \\
\hline
\end{tabular}

${ }^{55}$ N. Opačić, Reci mi to kratko i jasno, s. 169-170.

${ }^{56} \mathrm{Za}$ A. Starčević, Govorimo hrvatski ili 'hrvatski': standardni dijalekt i jezične ideologije u institucionalnom diskursu, „Suvremena lingvistika”, 81, 2016, s. 80. 
Ciekawych wyników dostarcza zestawienie normatywnych zaleceń chorwackich językoznawców z realnym uzusem obecnym w chorwackich korpusach językowych ${ }^{57}$, reprezentującym różne style funkcjonalne. Obecność turcyzmów w chorwackiej literaturze pięknej można zbadać na podstawie subkorpusu o nazwie knjižni potkorpus w ramach korpusu RIZNICA, który obejmuje przede wszystkim teksty literackie z XIX, XX i początku XXI wieku, ale także teksty o charakterze naukowym i popularnonaukowym do 2008 roku $^{58}$. Wyniki analizy frekwencji wyrazów tureckiego pochodzenia i ich odpowiedników w całym subkorpusie ,literackim” wykazały istotne różnice w zależności od konkretnej formy (por. Wykres 1) ${ }^{59}$. Najczęstszym turcyzmem jest ma(h)ramica o frekwencji 46\% w stosunku do rodzimego odpowiednika rupčić/rubčić, następne w kolejności są wyrazy dućan (37\%), ma(h)rama (33\%) i dugme (31\%), a pozostałe trzy formy mają frekwencję poniżej $30 \%$. Warto podkreślić, że cztery najpopularniejsze słowa pojawiają się w twórczości słynnych chorwackich pisarzy z XIX ${ }^{60}$ i XX wieku, takich jak: August Šenoa, Antun Gustav Matoš, Eugen Kumičić, Milan Begović, Vladan Desnica, Mirko Božić czy Ivan Raos.

Wykres 1. Frekwencja turcyzmów i ich odpowiedników w subkorpusie „literackim”

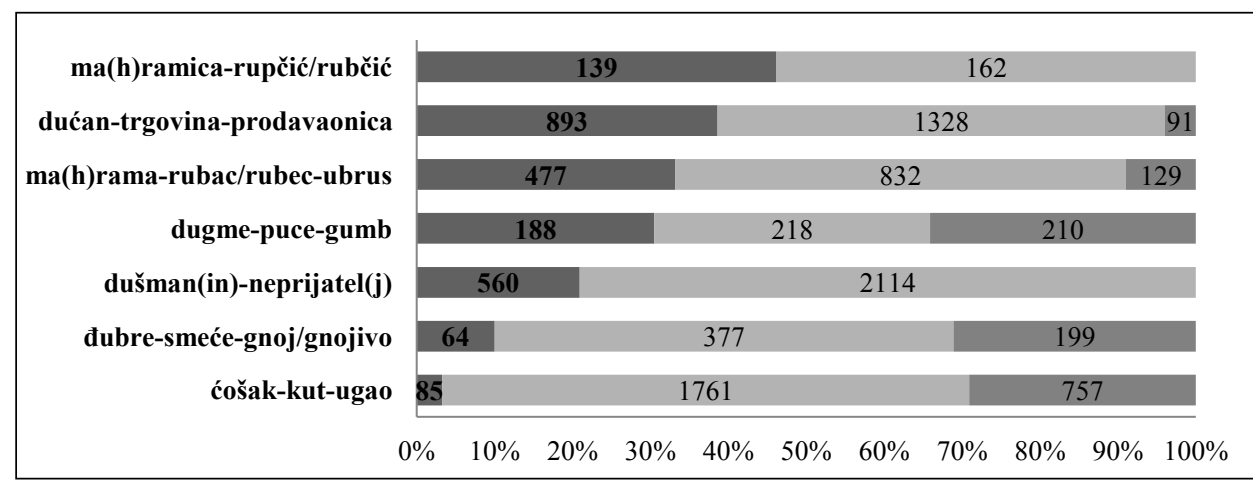

Jeśli jednak wziąć pod uwagę jedynie teksty wydane po 1990 roku, popularność turcyzmów znacząco spada (por. Wykres 2): frekwencję powyżej 20\% zachowują wyłącznie formy ma(h)rama $(36 \%)$ i ma(h)ramica $(25 \%)$, podczas gdy użycie wyrazów dućan i du-

${ }^{57}$ Od razu trzeba jednak zaznaczyć, że korpus RIZNICA, zamieszczony na stronach Instytutu Języka Chorwackiego (Institut za hrvatski jezik i jezikoslovlje), nie jest w pełni reprezentatywny, ponieważ nie istnieje ogólnodostępny szczegółowy spis wykorzystanych w nim źródeł, a subkorpus publicystyczny składa się niemal wyłącznie z artykułów konserwatywnego dziennika Vjesnik, por. A. Peti-Stantić, K. Langston, Hrvatsko jezično pitanje danas. Identiteti i ideologije, Srednja Europa, Zagreb 2013, s. 149. Drugi z korpusów - HNK (wersja 3.0) - jest z kolei bardzo awaryjny, a ponadto składa się w największej mierze z tekstów zaczerpniętych z chorwackiego dziennika ustaw Narodne novine.

${ }^{58} \mathrm{http}: / /$ riznica.ihjj.hr

${ }^{59}$ Przy analizie frekwencji pod uwagę brano tylko podstawowe formy danych turcyzmów występujące w tych samych lub zbliżonych znaczeniach, co ich odpowiedniki. Należy jednak podkreślić, że nie w każdym przypadku chodzi o dokładne synonimy. Turcyzmy w konkretnych rubrykach wykresów wymieniane są zawsze na pierwszym miejscu.

${ }^{60}$ Czyli jeszcze przed ukonstytuowaniem się wspólnego języka serbsko-chorwackiego. 
gme gwałtownie maleje: odpowiednio do $13 \%$ i $8 \%$. Wspomniane tutaj turcyzmy pojawiają się jednak w twórczości współczesnych chorwackich pisarzy, takich jak Nedeljko Fabrio, Roman Simić czy Goran Tribuson, zwykle w tradycyjnych kontekstach, np.: marama jako nakrycie głowy: Preko krupnoga je tijela imala prebačen izlizani crveni kućni kaputić, a na glavi zelenu maramu ispod koje su provirivali pramenovi prosijede kose ${ }^{61}$; maramica 'chusteczka do nosa': Mladić slegne ramenima. - Nekima se sviđa. A istina je... - ispuhne nos u maramicu. -... da zapravo ne znam voziti ${ }^{62}$; dućan 'sklep': Najbolje je da ga stavite u džep i izađete iz dućana na prstima ${ }^{63}$, z kolei dugme w przeniesionym znaczeniu 'przycisk': Da, da ... znam ... silno je skup ... - promrmljao je Računovođa i pritisnuo dugme na stolu, nakon čega su se vrata otvorila i na njima se pojavio čovjek u odijelu, onaj isti koji je Banića doveo ovamo ${ }^{64}$.

Wykres 2. Frekwencja turcyzmów i ich odpowiedników w subkorpusie „literackim” po 1990 roku

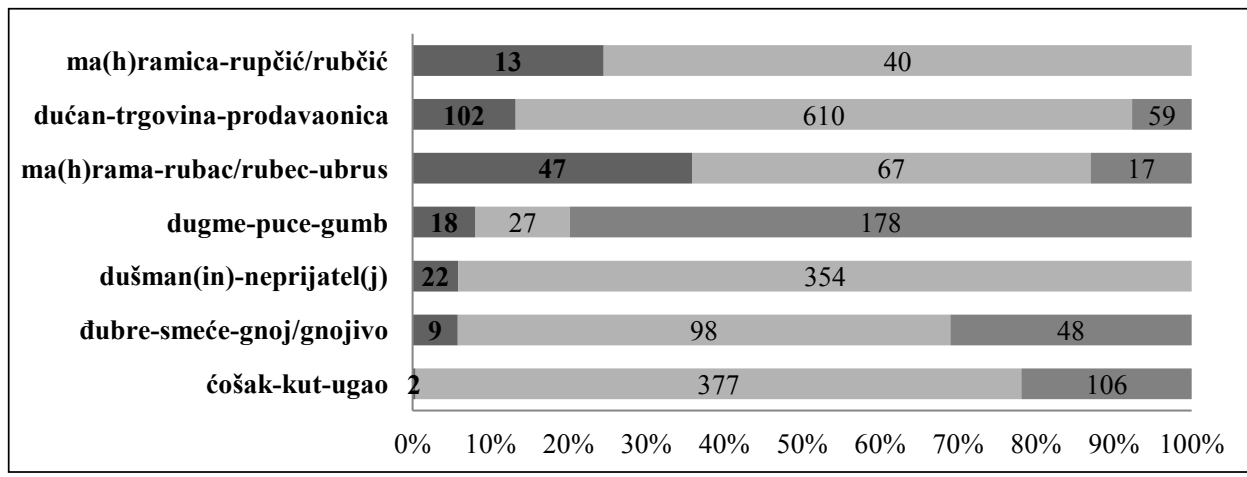

Te same wyrazy tureckiego pochodzenia mają również najwyższą frekwencję w subkorpusie prasowym (tiskovine), części korpusu RIZNICA, obejmującym głównie internetowe wydania konserwatywnego dziennika Vjesnik z lat 2000-200765 (por. Wykres 3). W przeciwieństwie jednak do tekstów literackich turcyzmy marama i maramica ${ }^{66}$ zdecydowanie dominują nad leksemami rodzimymi, uzyskując odpowiednio frekwencję 73\% i 69\%, z kolei turcyzm dugme jest niemal tak samo częsty jak węgierskie zapożyczenie gumb i występuje w $44 \%$ przypadków ${ }^{67}$. Znacznie niższą frekwencję ma za to dućan, bo niespełna $6 \%$, wynikać to może jednak z szerokiego ogólnego zastosowania najczęstszego rodzimego odpowiednika - trgovina. Pozostałe analizowane tutaj wyrazy używane są sporadycznie.

\footnotetext{
${ }^{61}$ http://riznica.ihjj.hr: R. Simić, Mjesto na kojem ćemo provesti noć, Zagreb 2000.

${ }^{62}$ Ibidem: R. Simić, Mjesto na kojem ćemo provesti noć, Zagreb 2000.

${ }^{63}$ Ibidem: G. Tribuson, Gorka čokolada, Zagreb 2004, s. 241.

${ }^{64}$ Ibidem, s. 205.

${ }^{65} \mathrm{http}$ ://riznica.ihjj.hr/philologic/Tiskovine.whizbang.form.hr.html

${ }^{66}$ Nie wzięto tutaj, rzecz jasna, pod uwagę obecnych również w subkorpusie terminów medycznych 'opłucna' i 'otrzewna'.

${ }^{67} \mathrm{~W}$ analizie nie uwzględniono nazwy zespołu Bijelo dugme, która pojawia się w subkorpusie aż 112 razy.
} 
Wykres 3. Frekwencja turcyzmów i ich odpowiedników w publicystyce (Vjesnik online 2000-2007)

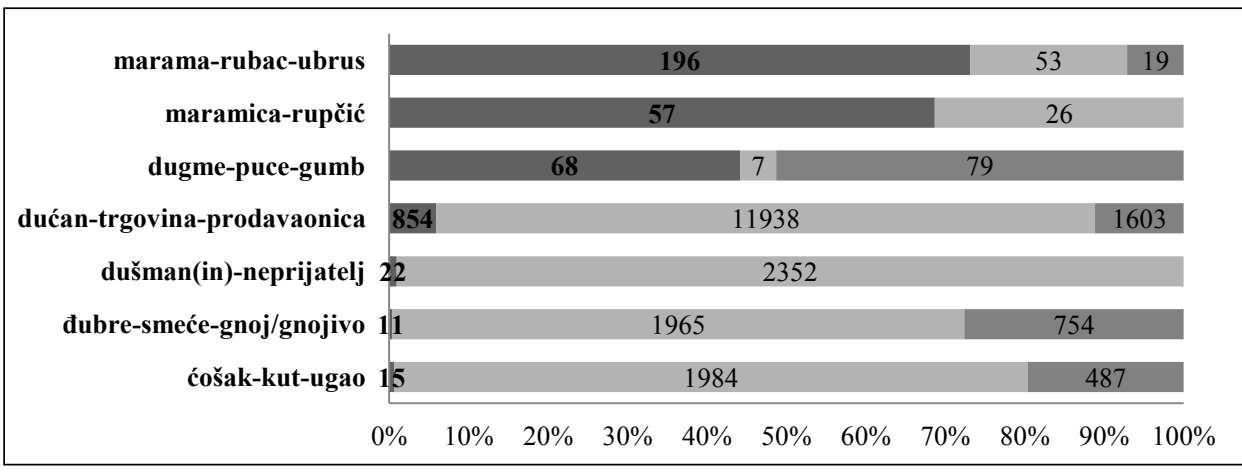

Warto podkreślić, że powszechnie występujące w chorwackiej publicystyce turcyzmy pojawiają się w nowych kontekstach i kolokacjach ${ }^{68}$. Leksem marama, oprócz tradycyjnych użyć, funkcjonuje w tekstach dziennikarskich jako 'pareo': Oko strukova tih visokih $i$ vitkih dama vijorile su se prozirne marame (parei) ispod kojih su se nazirale zamamne obline u gaćama »na mercedes «"69, 'bandana': Bila je to jedna nosiva, suvremena kolekcija sa njegovim prepoznatljivim chic potpisom, a sve je zaokružio uz nove modele kruna, grijača za uši i bandana marama ${ }^{70} \mathrm{czy}$ 'islamska chusta': Predsjednik parlamentarne grupe demokršćanske Unije CDU/CSU Friedrich Merz oštro se protivi pojavi nošenja marama od strane učiteljica islamske vjeroispovjesti ${ }^{71}$. Maramica może z kolei oznaczać 'chusteczki higieniczne’: Nepoznati je počinitelj zatražio papirnate maramice i kada je prodavačica otvorila blagajnu, kradljivac je zgrabio 1500 kuna iz ladice i pobjegao ${ }^{72}$ oraz 'chusteczki nawilżane': Unuka Kosjenka kaže kako MondiPro, koji proizvodi i vlažne maramice za čišćenje šminke, protiv uboda komaraca, za kućne ljubimce..., drži oko $10 \%$ tržišnog kolača od oko 25 mil. komada godišnje ${ }^{73}$. Co ciekawe, w Vjesniku odnaleźć można również przykłady użycia tego turcyzmu w kontekście medycznym jako 'otrzewna' lub 'opłucna', np.: Naime, Krojfu je bila amputirana lijeva potkoljenica, tri prsta na ruci, uništena mu je plućna maramica... ${ }^{74}$, chociaż w chorwackich słownikach to znaczenie zanika lub jest nacechowane.

Spośród pozostałych form na uwagę zasługuje wyraz dugme, który funkcjonuje jako element różnych nowoczesnych urządzeń, np. telefonu: Potom upalim svjećice, pogasim ostalu rasvjetu zbog ugođaja, i stisnem dugme na telefonskoj automatskoj sekretarici ${ }^{75}$ oraz w częstej kolokacji nuklearno dugme 'przycisk nukelarny': Međutim, jedna je ključna

\footnotetext{
${ }^{68}$ Oprócz zamieszczonych w korpusie RIZNICA artykułów z dziennika Vjesnik wykorzystano tu internetowe archiwum dziennika Večernji list z lat 2008-2017: https:/www.vecernji.hr/pretraga.

${ }^{69} \mathrm{http}$ ://riznica.ihjj.hr: Vjesnik online, 3.08.2000.

${ }^{70} \mathrm{https}: / / w w w . v e c e r n j i . h r:$ Večernji list, 11.10.2016.

${ }^{71}$ http://riznica.ihjj.hr: Vjesnik online, 5.12.2000.

${ }^{72}$ Ibidem: 23.01.2000.

${ }^{73} \mathrm{https}$ ://www.vecernji.hr: Večernji list, 12.10.2016.

${ }^{74} \mathrm{http}: / /$ riznica.ihjj.hr: Vjesnik online, 16.03.2001.

${ }^{75} \mathrm{https}$ ://www.vecernji.hr: Večernji list, 1.06.2013.
} 
razlika, tada je bilo jasno tko odlučuje o pritisku na nuklearno dugme ${ }^{76}$. W kontekście nowych realiów pojawia się również leksem dućan na oznaczenie różnego rodzaju nowoczesnych sklepów, np. internetowych: Objašnjava da prema nekim podacima ukupna vrijednost on-line prometa u Hrvatskoj čini manje od jedan posto ukupne vrijednosti prometa, pa je stoga njihov web dućan značajno iznad hrvatskog prosjeka ${ }^{77}$, ale także biznesu, głównie związanego ze sportem: Čelnici Atletica su nekoliko puta ove sezone ponovili: | IIl ćemo prodati Falcaa ili ćemo |'ugasiti svjetlo i zatvoriti dućan|' '’. $\left.\right|^{78}$ Należy również odnotować, że turcyzm dušmanin często odwołuje się do wojny z lat 1991-1995 i oznacza po prostu Serbów, np.: No kolikogod je svaki novi crveni krov najbolji odgovor dušmanima koji su razarali naš grad, toliko se u mojim, a vjerujem u mislima i mnogih Vukovaraca, javi tuga za nekom starom kućom koje su odisale pravim vukovarskim duhom ${ }^{79}$, z kolei đubre stanowi już głównie pejoratywne określenie człowieka, stąd jest jego częsta obecność w różnego rodzaju cytatach, np.: Ali suca nisam nazvao ni đubretom ni smećem-kaže Glavaš ${ }^{80}$.

Ostatnim źródłem, które zostało zanalizowane pod kątem obecności turcyzmów, jest zbiór tekstów o charakterze urzędowo-administracyjnym zamieszczonych w chorwackim dzienniku ustaw Narodne novine z lat 1990-2013 ${ }^{81}$. Ze względu na swój oficjalny charakter styl urzędowy może w oczach użytkowników danego języka uchodzić za swoisty wzorzec poprawności językowej, który w największym stopniu podlega standaryzacji, w związku z czym najłatwiej usunąć z niego niechciane formy. Tymczasem analiza chorwackiego korpusu pokazuje, że najpopularniejsze turcyzmy pojawiają się w tekstach urzędowych w podobnym stopniu jak we wspomnianych wcześniej źródłach publicystycznych: maramica w 84\% przypadków, marama - w 50\%, a dugme - w 36\%. Pozostałe wyrazy tureckiego pochodzenia występują tutaj bardzo rzadko (dućan, ćošak - poniżej 1\%) lub w ogóle (dušmanin, đubre).

Wykres 4. Frekwencja turcyzmów i ich odpowiedników w stylu urzędowym (Narodne novine 1990-2013)

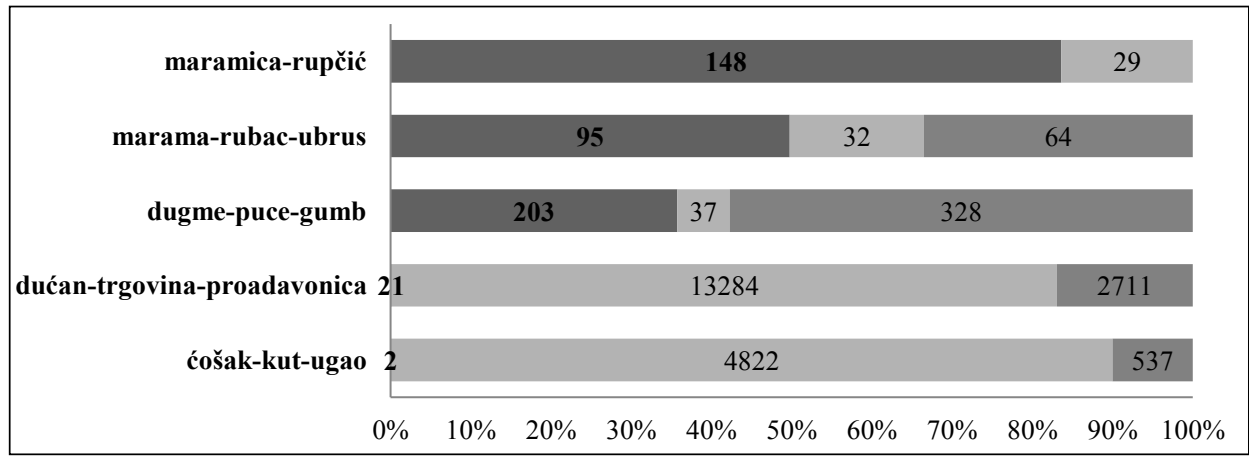

\footnotetext{
${ }^{76}$ Ibidem: 27.08.2016.

${ }^{77}$ http://riznica.ihjj.hr: Vjesnik online, 12.03.2005.

${ }^{78}$ https://www.vecernji.hr: Večernji list, 16.12.2012.

${ }^{79}$ http://riznica.ihjj.hr: Vjesnik online, 4.09.2001.

${ }^{80} \mathrm{https}: / / w w w . v e c e r n j i . h r:$ Večernji list, 28.05.2009.

${ }^{81} \mathrm{http}$ //filip.ffzg.hr/cgi-bin. Ze względu na usterki w działaniu korpusu wzięto pod uwagę cały subkorpus, czyli również teksty z 1990 roku. Także w tym przypadku przy analizie frekwencji pominięto kontekst medyczny turcyzmu maramica, ze względu na brak użycia w tej funkcji najczęstszego rodzimego odpowiednika - rupčić.
} 
W analizowanych tekstach urzędowych dominują tradycyjne znaczenia poszczególnych wyrazów, jednakże najczęściej użyte w bardzo oficjalnym kontekście, np. marama i dugme jako elementy służbowego uniformu: Marama svečana izrađuje se u tkanom vezu, tamno plave/svijetlo sive boje sa stiliziranim znakom MUP-a žute/plave boje ${ }^{82}$; Kada se, u ljetnom razdoblju, košulja kratkih rukava nosi kao vanjski dio službene vojne odore, nosi se bez kravate i otkopčanog gornjeg dugmeta ${ }^{83}$. Wyraz dugme ma tutaj także szerokie zastosowanie w znaczeniu 'przycisk', np. jako wyposażenie windy mechanicznej: Dizalica se mora uputiti samo s mjesta njezinog pogona. Upravljanje mora biti automatsko povratnog tipa (dugmad bez zaustavljanja)... ${ }^{84}$. Podobnie jak w korpusie prasowym, leksem maramica, oprócz typowych kontekstów, np.: Za postizavanje mikrobicidnog djelovanja vlažnih maramica mogu se koristiti samo konzervansi iz Liste VI ${ }^{85}$, pełni często funkcje terminów medycznych (weterynaryjnych), np.: topljena životinjska mast dobivena topljenjem pri niskoj temperaturi iz svježeg masnog tkiva srca, trbušne maramice, bubrega i mezenterija goveda i masnoće iz rasjekavaonica ${ }^{86}$.

W nawiązaniu do hipotezy postawionej na początku artykułu, po przeprowadzeniu dokładnej analizy poszczególnych wyrazów, można stwierdzić, że turcyzmy należące do grupy 3. klasyfikacji D. Brozovicia są zróżnicowane zarówno pod względem stopnia planowania korpusu, jak i frekwencji w poszczególnych typach tekstów. W zależności od konkretnego źródła normatywnego polityka językowa wobec analizowanych turcyzmów wyglądała odmiennie, jednakże tylko niektóre z nich, i to nie we wszystkich opracowaniach, uznane zostały za elementy jednoznacznie serbskie. Ponadto źródła z XXI wieku wykazują nieco mniejsze natężenie planowania języka. Pomimo różnic w podejściu autorów słowników i poradników językowych do analizowanych tutaj turcyzmów, zestawienie ich frekwencji w odmiennych typach tekstów (artystycznych, publicystycznych, urzędowych) pokazuje, że te same formy zachowały dziś popularność, inne zaś, niezależnie od rodzaju korpusu, zanikają.

Na podstawie rezultatów analizy siedmiu leksemów można zaproponować próbną klasyfikację omawianych tu turcyzmów. Za najistotniejsze kryteria podziału uznano natężenie planowania wobec tych wyrazów na podstawie sześciu poradników językowych (BROD, KRM, ŠIM, HJS, PROT, MAT) ${ }^{87}$ oraz ich frekwencję w stosunku do „lepszych” odpowiedników we współczesnych tekstach publicystycznych i urzędowych. Pozwoliło to na wyróżnienie czterech typów turcyzmów:

1. Planowanie: $\geq 50 \%$; frekwencja w tekstach publicystycznych i urzędowych: $\geq 50 \%$ - należą tu turcyzmy marama i maramica, w przypadku których można uznać, że intensywne, szczególnie w latach 90. XX wieku, planowanie językowe się nie powiodło.

2. Planowanie: $\geq 50 \%$; frekwencja w tekstach publicystycznych i urzędowych: $10-50 \%$ - należy tu wyraz dugme, który pomimo intensywnego planowania, występuje $\mathrm{w}$ analizowanych tekstach niewiele rzadziej niż jego zalecane odpowiedniki.

\footnotetext{
${ }^{82}$ Ibidem: Narodne novine, 100/2013.

${ }^{83}$ Ibidem, 58/2011.

${ }^{84}$ Ibidem, 23/2009.

${ }^{85}$ Ibidem, 197/2003.

${ }^{86}$ Ibidem, 99/2007.

${ }^{87}$ Dwa najnowsze poradniki (HMĆ, OPA) nie zostały wzięte pod uwagę ze względu na potencjalny brak możliwości oddziaływania na analizowany korpus tekstów.
} 
3. Planowanie: $\geq 50 \%$; frekwencja w tekstach publicystycznych i urzędowych: $<10 \%$ - leksemy đubre i ćošak, wobec których działania normatywne zakończyły się sukcesem.

4. Planowanie: $<50 \%$, frekwencja w tekstach publicystycznych i urzędowych: $<10 \%$ - dućan i dušman(in) nie podlegały intensywnej polityce językowej (nie było takiej potrzeby) i utrzymały niską frekwencję.

Zaproponowana powyżej klasyfikacja opiera się na niewielkiej liczbie przebadanych wyrazów, w związku z czym może jeszcze ulec dalszym zmianom po rozbudowaniu analizy o takie turcyzmy, jak np.: alat, bunar, đon, dželat, fitilj, galama, sanduk czy šamar. Badanie natężenia planowania wobec tego typu wyrazów należy z pewnością poszerzyć o kolejne poradniki i słowniki różnic powstałe w latach 90. XX wieku i w XXI wieku. W celu analizy frekwencji warto wykorzystać większą liczbę korpusów prasowych i literackich, ale też np. fora internetowe jako źródło leksyki potocznej młodych Chorwatów. Wydatnym uzupełnieniem analizy korpusowej byłoby sięgnięcie po metodę ankietową, która pomogłaby odpowiedzieć na pytania: jaki jest stosunek Chorwatów do turcyzmów, czy preferują rodzime odpowiedniki oraz w jakich sytuacjach korzystają z wyrazów tureckiego pochodzenia.

\section{Bibliografia}

Anić V., Veliki rječnik hrvatskoga jezika (elektronsko izdanje) [ANIĆ], Novi Liber, Zagreb 2003.

Babić S., Finka B., Moguš M., Hrvatski pravopis: s pravopisnim rječnikom (wyd. 4), Školska knjiga, Zagreb 1996.

Barić E. (red.), Hrvatski jezični savjetnik [HJS], Institut za hrvatski jezik i jezikoslovlje, Zagreb 1999.

Benešić J., Gramatyka języka chorwackiego, czyli serbskiego, Bibljoteka Polska, Warszawa 1947.

Benešić J., Słownik chorwacko-polski [BEN], Nakladni zavod hrvatske, Zagreb 1949.

Brodnjak V., Razlikovni rječnik srpskog i hrvatskog jezika [BROD], Školske novine, Zagreb 1991.

Broz I., Iveković F., Rječnik hrvatskoga jezika [BROZ], Štamparija Karla Albrechta (Jos. Wittasek), Zagreb 1901.

Brozović D., Odoše Turci, ostaše turcizmi, „Vijenac”, 173/2000. http://www.matica.hr/Vijenac/Vij173. nsf (dostęp: 18.03.2019).

Czerwiński M., Język-ideologia-naród. Polityka językowa w Chorwacji a język mediów, Scriptum, Kraków 2005.

Deanović M., Jernej J., Hrvatsko ili srpsko-taljanski rječnik (wyd. 4) [DEAN], Školska knjiga, Zagreb 1975.

Fałowski P., Postavení, frekvence a funkce některých turcismů v současné chorvatštině, [w:] P. Boček, L. Hladký, P. Pilch, P. Stehlík, V. Štěpánek (red.), Studia Balkanica Bohemoslovaca; 7, Příspěvky přednesené na VII. mezinárodním balkanistickém sympoziu v Brně ve dnech 28.-29. listopadu 2016, Moravské zemské muzeum: Ústav slavistiky Filozofické fakulty Masarykovy univerzity, Brno 2017, s. 657-674.

Greenberg R., Jezik i identitet na Balkanu. Raspad srpsko-hrvatskoga, thum. A. Peti-Stantić, Srednja Europa, Zagreb 2005.

Hrvatski jezični portal [HJP], http://hjp.znanje.hr/, (dostęp: 18.03.2019).

Hudeček L., Matković M., Ćutuk I., Jezični priručnik Coca-Cole HBC Hrvatska - hrvatski jezik o poslovnoj komunikaciji (wyd. 2) [HMĆ], Coca-Cola HBC Hrvatska d.o.o., Zagreb 2012, http://www.prirucnik.hr, (dostęp: 18.03.2019). 
Hrvatski nacionalni korpus [HNK], http://filip.ffzg.hr/cgi-bin/run.cgi/first_form, (dostęp: 18.03.2019).

Jaroszewicz H., Nowe tendencje normatywne w standardowych językach chorwackim i serbskim, Wydawnictwo Uniwersytetu Opolskiego, Opole 2004.

Jojić Lj. (red.), Veliki rječnik hrvatskoga standardnog jezika [VRH], Školska knjiga, Zagreb 2015. Krmpotić M., Jezični priručnik [KRM], Hrvatska radiotelevizija, Zagreb 1992.

Matković M., Jezični savjetnik [MAT], Škorpion, Zagreb 2006.

Opačić N., Reci mi to kratko i jasno (wyd. 2) [OPA], Znanje, Zagreb 2015.

Peti-Stantić A., Langston K., Hrvatsko jezično pitanje danas. Identiteti i ideologije, Srednja Europa, Zagreb 2013.

Pranjković I., O aktualnosti Matičina razlikovnog rječnika iz 1940. godine, [w:] I. Pranjković, Ogledi o jezičnoj pravilnosti, Disput, Zagreb 2010, s. 149-155.

Protuđer I., Hrvatski u šaci [PROT], Naklada Protuđer, Split 2003.

Riznica Instituta za hrvatski jezik i jezikoslovlje [RIZNICA], http://riznica.ihjj.hr, (dostęp: 18.03.2019).

Rječnik hrvatskoga ili srpskoga jezika, t. 1-23, [JAZU], Jugoslavenska Akademija Znanosti i Umjetnosti, Zagreb 1880-1976.

Skok P., Etimologijski rječnik hrvatskoga ili srpskoga jezika, t. 1-4, [SKOK], Jugoslavenska Akademija Znanosti i Umjetnosti, Zagreb 1971-1974.

Starčević A., Govorimo hrvatski ili 'hrvatski': standardni dijalekt i jezične ideologije u institucionalnom diskursu, ,Suvremena lingvistika”, 81, 2016, s. 67-103.

Šimundić M., Rječnik suvišnih tuđica u hrvatskomu jeziku [ŠIM], Barka, Zagreb 1994.

Škaljić A., Turcizmi u srpsko-hrvatskom jeziku, „Svjetlost” Izdavačko preduzeće, Sarajevo 1966.

Šonje J. (red.), Rječnik hrvatskoga jezika [ŠONJE], LZ Miroslav Krleža i Školska knjiga, Zagreb 2000.

Vjesnik online, http://riznica.ihjj.hr/philologic/Tiskovine.whizbang.form.hr (dostęp: 18.03.2019).

Večernji list (arhiva), https://www.vecernji.hr/pretraga (dostęp: 18.03.2019).

Vranić S., Zubčić S., Turcizmi u frazemima hrvatskih govora, „Filologija”, 60, 2013, s. 103-145.

Przemysław Fałowski, dr, bohemista i kroatysta, językoznawca, adiunkt w Instytucie Filologii Słowiańskiej Uniwersytetu Jagiellońskiego. Jego główne zainteresowania naukowe dotyczą historii języków słowiańskich, dialektologii czeskiej i chorwackiej, słowiańskiej leksyki potocznej oraz procesów standaryzacyjnych we współczesnym języku chorwackim; autor m.in. monografii Sposoby wzbogacania leksyki potocznej w języku czeskim i chorwackim (Kraków 2015).

przemyslaw.falowski@uj.edu.pl

ORCID: 0000-0003-1039-3496 